\title{
THE SPECIES OF RASTRELLIGER IN THE JAWA SEA, THEIR TAXONOMY AND MORPHOMETRY (PERCIFORMES, SCOMBRIDAE) ${ }^{1}$ )
}

\author{
by \\ TATANG SUJASTANI $^{2}$ ) \\ (Received 19 November 1974)
}

\begin{abstract}
Analyses of morphometric data suggest that there are two species within the genus Rastrelliger, namely brachysoma and kanagurta. Rastrelliger neglectus is considered to be a synonym of $R$. brachysoma.

Both species exhibit intraspecific geographical variations in some of their morphological characters.

The characters that exhibit sexual dimorphisms, strong allometric growth, and geographical variations are described.

The description of the genus and a key to the species are given.

\section{IKHTISAR}

Analisa data morfometri menunjukkan adanya dua species dalam marga Rastrelliger yakni brachysoma dan kanagurta. $R$. neglectus dianggap sebagai sinonim $R$. brachysoma.

Kedua species tersebut memiliki variasi-variasi geografi intra-spesifik pada beberapa sifat-sifat morfologi mereka menurut penyebarannya.

Sifat-sifat yang menunjukkan dimorfisme kelamin, pertumbuhan alometri yang jelas, dan variasi-variasi geografi dipertelakan.

Pertelaan marga dan kunci determinasi untuk species diterakan.
\end{abstract}

\section{INTRODUCTION}

Ikan kembung, the genus Rastrelliger, constitutes one of the most important groups of fishes in the artisanal fisheries of Indonesia.

$\left.{ }^{1}\right)$ Contribution of the Lembaga Penelitian Perikanan Laut, Departemen Pertanian.

$\left.{ }^{2}\right)$ Lembaga Penelitian Perikanan Laut, Jakarta, Indonesia. 


\section{T. SUJASTANI}

The most important study of Rastrelliger taxonomy in this region was conducted by DE BEAUFORT \& CHAPMAN (1951). No other work has been done since.

In spite of the extensive general investigations being done in the neighbouring states, such as Thailand and India, the nomenclature of the species is still in doubt. Many synonyms exist because local races or individuals have been described under different names.

The taxonomic position of the genus Rastrelliger has been accepted since JORDAN and STARKS (1908) proposed it for the mackerel having long gill-rakers. STARKS (1921) raised the subgenus Pneumatophorus as a genus beside the genera Scomber and Rastrelliger. However, FRASERBRUNNER (1950) and COLLETTE \& GIBBS (1963) recognized only two genera, Scomber and Rastrelliger.

There are several interpretations at the species level. DE BEAUFORT \& CHAPMAN (1951) listed three species, Rastrelliger brachysoma $R$. neglectus, and $R$. kanagurta. They noted that $R$. brachysoma may be a variant of $R$. neglectus. MANACOP (1956) described only two species, $R$. brachysoma and $R$. chrysozonus. He further stated that $R$. neglectus was a synonym of $R$. brachysoma and $R$. kanagurta was a synonym of $R$. chrysozonus. JONES \& SILAS (1962) recognized two species and considered $R$. neglectus as a synonym of $R$. brachysoma, and opposed DE BEAUFORT \& CHAPMAN's (1951) description. Their incomplete evidence caused some confusions among the workers in Indonesia and adjacent regions who still recognized and used DE BEAUFORT \& CHAPMAN's work. DRUZHININ (1968) supports DE BEAUFORT \& CHAPMAN and states that he is not in agreement with JONES \& SILAS (1962), however, without strong arguments. MATSUI (1967) proposed a new species, $R$. faughni, which formerly was named Scomber australasicus and recognized two other species, $R$. brachysoma and $R$. kanagurta. His proposal is still widely questioned. The controversy, thus, rests on whether $R$. brachysoma and $R$. neglectus are different species.

This paper is aimed at veryfying the species identities and studying the morphometry. It is expected that the result will be useful for further studies, especially on aspects of population.

\section{MATERIALS AND METHODS}

During the 1972 fishing season, samples of Rastrelliger were collected from the two main fishing areas in the Jawa Sea, i.e., Tanjung Satai 


\section{THE SPECIES OF RASTRELLIGER IN THE JAWA SEA}

in the South West of Kalimantan and Jakarta in the North Coast of Java (Fig. 1).

All of the fishes were collected from the same fishing gear, the shore seine, having stretched mesh-size of about 3.0 to $4.5 \mathrm{~cm}$.

The samples were temporarily preserved in $10 \%$ formalin (+ borax, to retard shrinkage) and transferred to 37\% isopropylalcohol.

Measurements were made by using dial caliper and a metric scale. Sixteen morphometric, seven meristic and some qualitative characters were examined. The counting and evaluation of characters were based on large series of specimens. Proportions were calculated from the numbers of specimens mentioned in the description or appearing in the tables. Meristic characters were determined from radiographs.

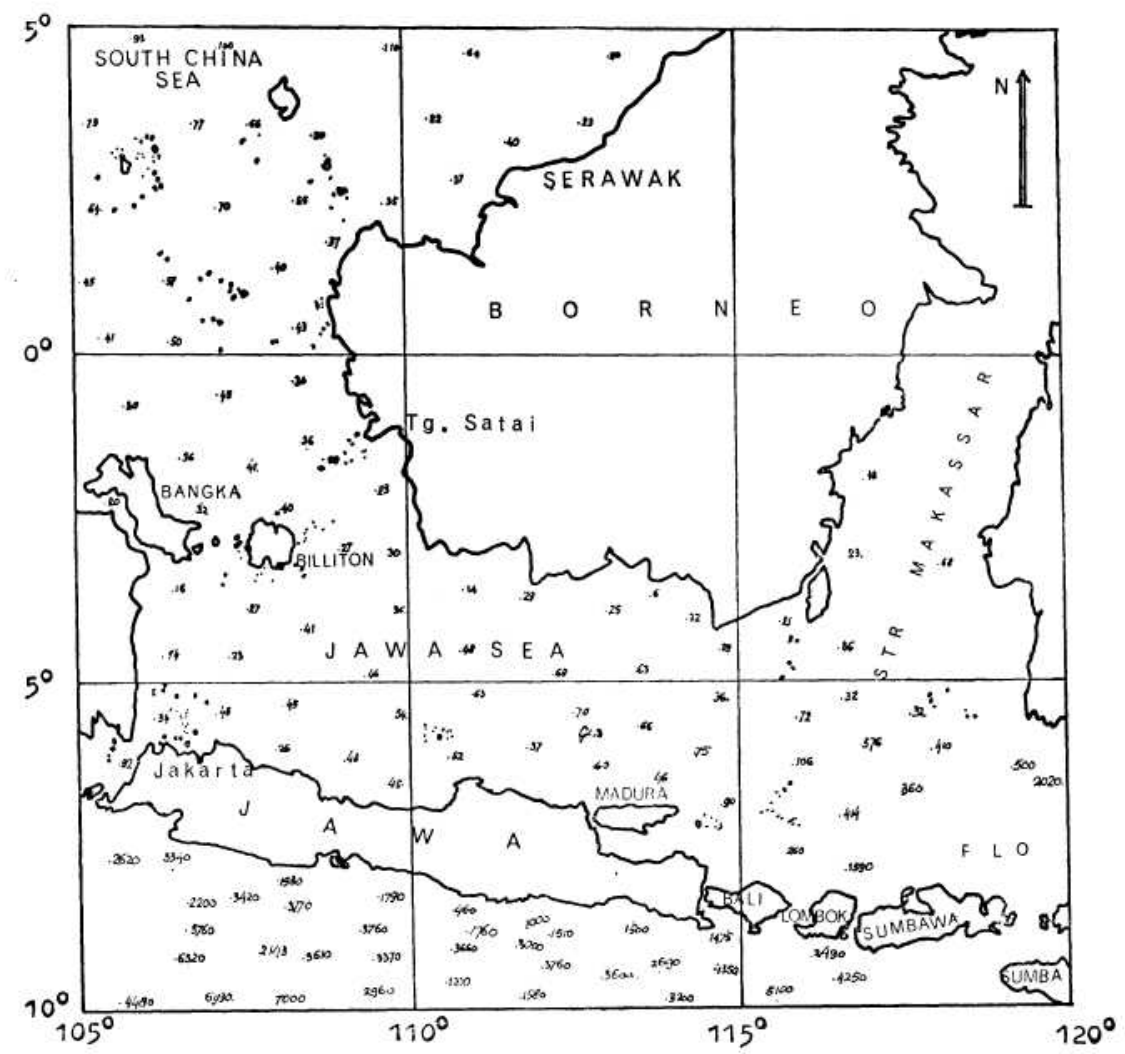

Figure 1. Bathymetric chart of the Java Sea (depth in meters). 


\section{T. SUJASTANI}

Clearing and staining were done for bone structure examinations. The measurements and counts used in this study are those defined by HuBBS \& LAGLER (1964). Each morphometric character was subjected to regression analysis. Regression lines were compared by covariance analysis.

\section{Systematic Study}

\section{RESULT}

\section{Rastrelliger JORDAN \& STARKS}

Rastrelliger JORDAN \& STARKS 1908: 607 (ortho-type: Scomber brachysoma BLEEKER 1851).

Description. - The ratio of values of fork length (FL) to geatest body depth ranges from 3.10 to 4.40 (Table I).

The distribution of sympatric samples shows two distinct bimodal histograms with no overlap.

The degrees of intergradation among samples are in Table I which suggest that these characters are useful in distinguishing the species. The average ratios of head length to greatest body depth range from 0.89 to 1.22 (Table II).

The frequency distribution of these ratios for sympatric samples shows two distinct bimodal histograms with modes of 0.98, 1.01, and two modes of 1.10 .

The ratios of body length (BL), fork length (FL), and total length (TL) to head length, show considerable overlaps with degrees of intergradation range from $13.5-34.0 \%$ between sympatric samples; while the ratios to greatest body depth, the degrees of intergradation range from $0.0-2.1 \%$.

The length of intestine in FL (Table III) between sympatric samples shows no overlap; the degree of intergradation is $0.0 \%$.

The first group, i.e., samples no. 1 and no. 2 has ratios $2.2-2.95$ $\mathrm{x}=2.54$ ); whereas the second group, samples no. 3 and no. 4 , has ratios $1.32-1.38(\mathrm{x}=1.35)$.

Adult small, from 15 - 35 cm. Body fusiform, moderately compressed; body and cheeks covered with small scales, those of the breast larger than the others. Eyes with well developed adipose eyelid. Mouth moderately large, maxillary reaching to a point nearly vertical below posterior edge of eye. Small teeth in jaws. Vomer and palatine edentulous. Gill-rakers long and numerous, feather-like, visible when the 


\section{THE SPECIES OF RASTRELLIGER IN THE JAWA SEA}

mouth is opened. Two dorsals, the first spinous. Five or six finlets behind dorsal and anal. Caudal deeply forked. Pectorals short, pointed with broad base. Pelvics with spines and five rays. Marine, in large school, inshore. Feeds on both zoo- and phytoplankton.

Rastrelliger is at present considered to contain two species occuring in abundance throughout the Indo-Pacific Region, in tropical Indian Ocean and Western Pacific Ocean.

\section{Key to the species of Rastrelliger JORDAN \& STARKS}

1. Greatest body depth in FL $3.1-3.7(\overline{\mathrm{x}}=3.4)$; very finely dendritic cephalic lateral-line canal system; head length slightly less than greatest body depth, $0.89-1.07(\bar{x}=0.98)$; length of intestine in FL 2.2-3.0 $(\overline{\mathrm{x}}=2.5)$; digestive tract very convoluted R. brachysoma

2. Greatest body depth in FL $3.8-4.4(\overline{\mathrm{x}}=4.0)$; not finely dendritic cephalic lateral-line canal system; head length distinctly greater than greatest body depth, $1.01-1.19(\overline{\mathrm{x}}=1.11)$; length of intestine in FL $1.3-1.4(\overline{\mathrm{x}}=1.35)$; digestive tract less convoluted

R. kanagurta

\section{Rastrelliger brachysoma BLEEKER}

Scomber brachysoma BLEEKER 1851: 356 (descript., occ.)

Scomber kanagurta BLEEKER 1852: 34 (nee. CUVIER \& VALENCIENNES, descript.)

Scomber neglectus VAN KAMPEN 1907: 7 (descript.)

Rastrelliger brachysoma FOWLER 1928: 132 (morphometric descript.)

Rastrelliger neglectus DE BEAUFORT 1951: 211 (descript., fig., occ.)

Description. - Body compressed, greatest body depth 3.4 (3.1 - 3.7) in FL at origin of the seventh dorsal spine. Head length less than or slightly greater than greatest body depth, 0.98 (0.89 - 1.07); 3.5 (3.3 $3.7)$ in FL. Eye $1.0-1.2$ in snout, about equal to interorbital space. Mouth oblique, maxillary reaching to below hind border of eye. A single series of fine and pointed teeth in the jaws. Palate edentulous. Gillrakers 19 (17 - 21) on the upper limb and 35 (34 - 37) on the lower limb of the first left gill-arch, the longest ones equal or greater than the distance between snout and pupil. First dorsal spine shorter than second. Second dorsal fin concave. Anal fin similar to second dorsal; origin of anal slightly behind that of second dorsal. Pectoral triangular, longer than 


\section{T. SUJASTANI}

ventral; about equal or greater than postorbital part of head. Scales ctenoid. Lateral-line scales 125 (120-131); slightly curved. Measurements of 117 specimens on table IV.

Fin formulae: $\mathrm{D}_{1} \mathrm{XI}\left(\mathrm{X}\right.$ - XI); $\mathrm{D}_{2} 12(12$-13) + 5 (5 - 6); A 13 + 5 (5 - 6); $\mathrm{P}_{1} 18$ (16-18); $\mathrm{P}_{2}$ 1.5; vertebrae 31 (38 specimens).

Colour in life.- Bluish green in the back above lateral-line and silvery in the belly and sides below lateral-lines. A row of dark spots along base of first dorsal with dusky in colour. Pectoral, ventral, and anal fins yellowish hyaline with dusky margins. Caudal fin yellowish. Colouration of preserved specimens gradually fade to bluish grey and dull white.

Local common name.- Kembung Perempuan.

Local habitat: Coastal water of the Indonesian Archipelago.

Distribution: From Andaman Islands through Indonesian Archipelago to Fiji and Solomon Islands. Rarely found in South African waters.

\section{Rastrelliger kanagurta CUVIER}

Scomber kanagurta CUVIER 1817: 313 (descript.)

Scomber loo LESSON 1829: 277 (occ.)

Scomber chrysozonus RUPPELL 1835: 10 (occ, fig.)

Scomber microlepidotus RUPPELL 1835: 37 (descript., fig.)

Scomber moluccensis BLEEKER 1856: 40 (descript.)

Scomber ream DAY 1870: 690 (occ.)

Scomber lepturus AgAssiz 1874: tab. 2 (occ.)

Rastrelliger brachysoma JORDAN \& DICKERSON 1908: 610 (nee. BlEEKER, descript., occ, fig.)

Rastrelliger kanagurta JORDAN \& STARKS 1917: 440 (OCC)

Rastrelliger chrysozonus KISHINOUYE 1923: 406 (class., syn., descript., occ.)

Rastrelliger microlepidotus BARNARD 1923: 296 (occ.)

Rastrelliger serventyi WHITLEY 1944: 268 (descript, occ).

Description. - Body moderately compressed, greatest body depth 4.0 (3.8 - 4.4) in FL at the origin of the seventh dorsal spine. Head length distinctly greater than greatest body depth, 1.11 (1.01 - 1.19); 3.6 (3.5 - 3.7) in FL. Eye 1.2 - 1.4 in snout, equal to or slightly less than interorbital space. Mouth oblique, maxillary not reaching to a point below hind border of eye or not so far in young specimens. A single series of fine pointed teeth in the jaws. Palate and vomer edentulous. 


\section{THE SPECIES OF RASTRELLIGER IN THE JAWA SEA}

Gill-rakers 21 (18-23) on the upper limb and 37 (35-39) on the lower limb of the first left gill-arch; the longest equal to distance from pupil to snout. First dorsal spine shorter than second and equal to distance from snout to eye; last spine very small. Anterior ray of second dorsal fin longest, slightly less than fourth spine of first dorsal. The edge of second dorsal and anal fins concave. Origin of anal fin slightly behind that of second dorsal; similar in shape. Pectoral pointed and triangular. Scales ctenoid; lateral-line 130 (125-140). Measurements of 103 specimens on Table $\mathrm{V}$.

Fin formulae: $\mathrm{D}_{1}$ XI (IX-XI); $\mathrm{D}_{2} 12(12-13)+5(5-6)$; A $13+$ 5 (5-6); $\mathrm{P}_{1} 19$ (19-20); $\mathrm{P}_{2}$ 1.5; vertebrae 31 (40 specimens).

Colour in life.- Bluish with greenish grey stripes above and silvery yellowish below lateral-lines. Dark spots along the first dorsal base. Pectoral, ventral, and anal fins hyaline; dorsal and caudal dusky along margins. Colourations of preserved specimens gradually fade.

Local common names: Kembung Lelaki, Kembung, Banyar.

Local habitat: All over Indonesian waters.

Distribution: From Durban (South Africa), Persian Gulf, through Central Indo-Pacific Area, Ryukyu Island, Queensland (Australia), Fiji Island, to Hawaii Island.

\section{Nomenclature}

The frequency distribution of the ratios of head length to greatest body depth for Rastrelliger from the north coast of Jawa and Tanjung Satai (Fig. 2, Table II) is distinctly bimodal with a slight overlap. The degree of intergradation of the two sympatric samples are 5.6\% from the north coast of Jawa area and $2.2 \%$ from Tg. Satai area.

The frequency distribution of the ratios of greatest body depth (or height by several authors) to FL is also bimodal, and shows no overlap between these sympatric samples (Fig. 3, Table I).

The ratios of the length of intestine to FL show non-overlapping ranges, of which the degree of intergradation is $0.0 \%$ (Table III).

Those characters that belong to two groups exist sympatrically, with no intergradation between each other, and therefore, the two groups should be considered as two valid species. The first group including samples no. 1 and no. 2 is Rastrelliger brachysoma and the second group is $R$. kanagurta, containing samples no. 3 and no. 4. 


\section{T. SUJASTANI}

DE BEAUfORT \& CHAPMAN (1951) stated that he recognized $R$. neglectus VAN KAMPEN with the following arguments "Van Kampen (1907) pointed out, that the two common species of Rastrelliger in the Jawa Sea have been confused by BLEEKER and others. The species that BLEEKER called loo, is the same as that of French authors, but it is a synonym of kanagurta. The other species is mentioned by BLEEKER and others as kanagurta, and had therefore to be renamed. VAN KAMPEN called it neglectus". With regard to brachysoma, DE BEAUFORT \& CHAPMAN (1951) commented: "It was not 5, as stated by BLEEKER, but 6 finlets behind dorsal and anal, and differs from the other Indo-Australian species of Rastrelliger by its great depth".

In my opinion, VAN KAMPEN'S (1907) decision to name the species with great body depth as neglectus cannot be accepted, because BLEEKER in 1851 already named it brachysoma. His view probably was caused by BLEEKER's inadequate descriptions since it was described from a single specimen (120 mm long and without caudal fin).

Comparison of BLEEKER's (1851), VAN KAMPEN'S (1907) and DE BEAUFORT \& CHAPMAN (1951) data with that of the present study significantly suggests that $R$. neglectus VAN KAMPEN is a synonym of $R$. brachysoma BLEEKER; whereas the descriptions of CUVIER (1817) and DE BEAUFORT \& CHAPMAN (1951) are in agreement with the data of samples no. 3 and no. 4, i.e. R. kanagurta.

\section{Morphometric Study.}

For characters studied, the regression of each character on FL is a rectilinear regression, with correlation coefficients range from 0.71 0.99 (Tables VI, VII, VIII, IX).

$$
\mathrm{y}=\mathrm{a}+\mathrm{bx}
$$

where: $x$ the independent variable, fork length

$\mathrm{y}$ the dependent variable, length of any body part.

The characters were examined for possible bias caused by sexual dimorphism or strong allometric growth.

Analysis of covariance indicated that:

1. longitudinal measurements and pelvic fin length are significantly different (1\%) between sexes (Table $\mathrm{X}$ ),

2. perpendicular iris diameter and pupil diameter, pectoral fin length, and pectoral breadth show strong allometric growth (1\% level of significance, Tables XI, XII, XIII). 
THE SPECIES OF RASTRELLIGER IN THE JAWA SEA

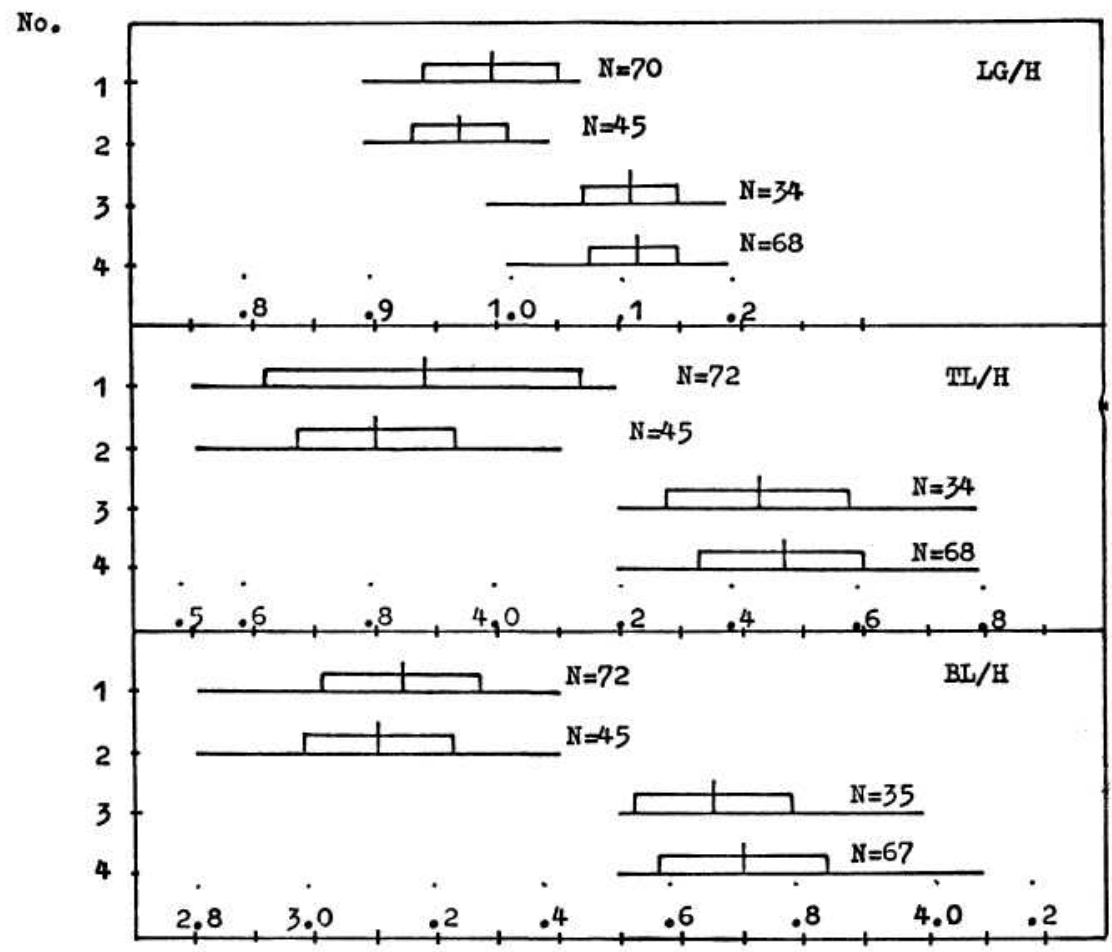

Figure 2. Graphic comparison of observed ranges and means. Ratio of head length, total length, and body length each to greatest depth (height) of four samples of Rastrelliger from two localities. Base line represents range; white bar, twice standard deviation; short vertical bar, mean.

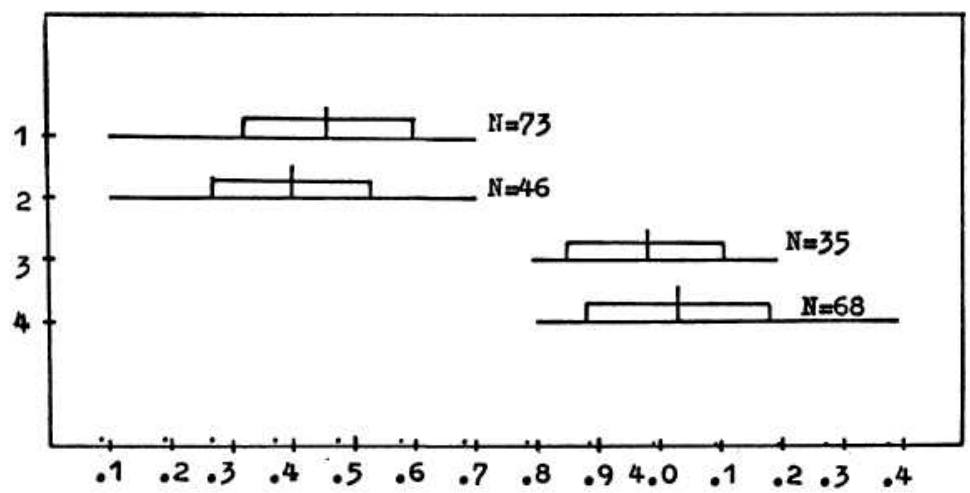

Figure 3. Graphic comparison of observed ranges and means. Ratio of fork length FL to greatest body depth (h) of Rastrelliger of four samples from two different localities. Base line represents range; white bar, twice standard deviation; short vertical bar, mean. 


\section{T. SUJASTANI}

Sexual dimorphism

Rastrelliger brachysoma shows sexual dimorphism in body length, maxillary length, ventral fin length, and probably caudal fin length (Table X).

The male has a shorter head, shorter maxillary, shorter ventral fin, shorter body, and probably shorter caudal fin (Fig. 4).

The purpose of this sexual dimorphism is not yet been studied in this particular fish. I speculate that this dimorphism is more for sexual purposes rather than for display; such as longer ventral fin in female is probably for obtaining better balance and diverging the eggs while discharging them. This dimorphism is less likely to appear in fins which are critical for locomotion. The longer body in female can be related to the need for more space in body cavity for eggs, as female gonads are generally much bigger than male gonads. The longer head and maxillary are probably related to the more intensive and active feeding in the female than in the male.

\section{Allometric growth}

The morphometric data of $R$. kanagurta suggest that perpendicular iris diameter and pupil diameter, pectoral fin length, and pectoral breadth show strong allometric growth (Tables XI, XII, XIII).

\section{Geographic variations}

Comparisons were done on head depth, dorsoventral depth, dorsoanal depth, greatest body depth and interorbital distance, since these characters show neither sexual dimorphism nor strong allometric growth in both species.

Analysis of covariance on the data indicated that:

1. between sympatric samples these characters show a very highly signi ficant difference $(0.01 \%)$;

2. the dorsoventral depth, greatest body depth, and interorbital distance have significant intraspecific difference $(5.0 \%)$, showing geogra phic variations in $R$. brachysoma (Table XX). The fish from Tg. Satai area posseses greater dorsoventral depth, greater body depth, and longer interorbital distance than its counterpart from the north coast of Java. In other words $R$. brachysoma from the north coast of Jawa is slenderer than that one from Tg. Satai (Fig. 5). 


\section{THE SPECIES OF RASTRELLIGER IN THE JAWA SEA}

3. R. kanagurta shows geographic variations in its head depth and dorsoventral depth (Table XX). The fish from the north coast of Jawa possess greater head depth and dorsoventral depth. Thus $R$. kanagurta from Tg. Satai is slenderer and has less head depth than the one from the north coast of Jawa (Fig. 6).

\section{Meristic characters}

Number of vertebrae. - Total numbers of vertebrae appeared to be constant as all specimens examined had 31 vertebrae. There is no difference between $R$. brachysoma and $R$. kanagurta.

First haemal spine. - The first haemal spine appears to be constant on the tenth vertebrae in Rastrelliger.

First dorsal spine. - The first dorsal spine counts appear to be variable between 10.6 (0.5 S.D.) to 11.0 (0.0 S.D.).

Analysis of variance indicates highly significant differences (1\%) between $R$. kanagurta from the north coast of Jawa and the one from Tg. Satai area. The fish from the former area has 11 spines on its first dorsal fin, whereas the one from the latter area is variable, either possessing 11 or 10 spines, $(\mathrm{x}=10.6, \mathrm{~S} . \mathrm{D} .=0.5, \mathrm{n}=20)$.

Dorsal fin rays and finlets. - The second dorsal finrays plus finlets counts appear to be less variable. The coefficients of variation range from 0 to $2.9 \%$. There is no significant difference between species.

The fin rays vary from 12 to 13 and the dorsal finlets from five to six.

Anal fin rays and finlets. - The counts of anal finrays plus anal finlets appears to be constant, i.e. 18. The rays are 13 and the finlets five to six.

First occurence of haemal brace. - The first haemal brace occurred as a structure on vertebrae as described by ROEDEL (1952). He suggested that this character is good for distinguishing race in Pneumatophorus.

This structure in Rastrelliger appears either on 13th or 14th vertebrae. The coefficients of variation range from 2.2 to 3.6. The means range from 13.7 (0.5 S.D.) to 13.9 (0.3 S.D.) with $n=20$.

Analysis of variance indicates that there is no significant difference between and within species. Therefore, this character cannot be used in racial studies of Rastrelliger spp.

Gill-raker. - The gill-raker counts on the first gill-arch show considerable variations. The coefficient of variation of the gill-raker counts 


\section{T. SUJASTANI}

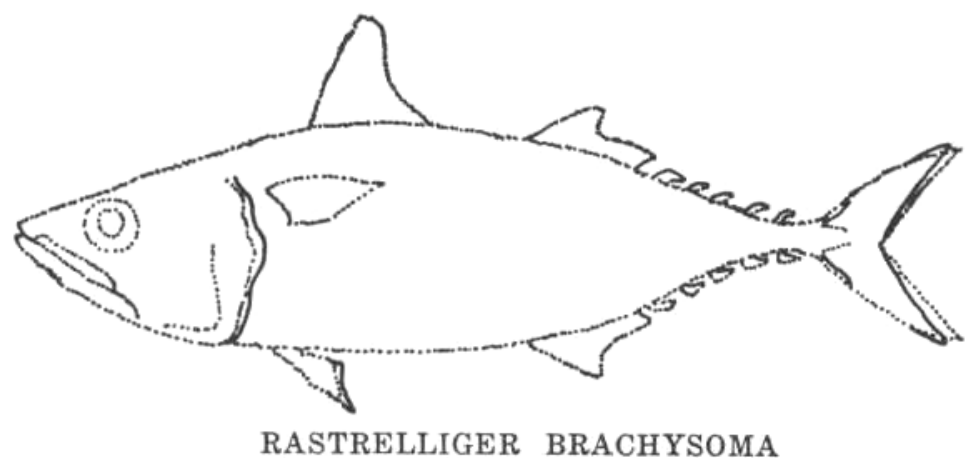

Figure 4. Sexual Dimarphisms.

........... male

female.

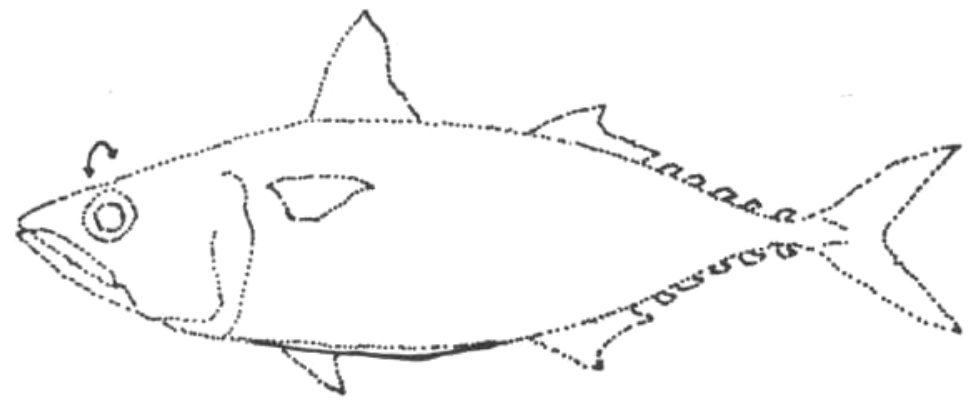

RASTRELLIGER BRACHYSOMA

Figure 5. Geographic Variations.

.......... from the north coast of Java from $\mathrm{Tg}$. Satai area.

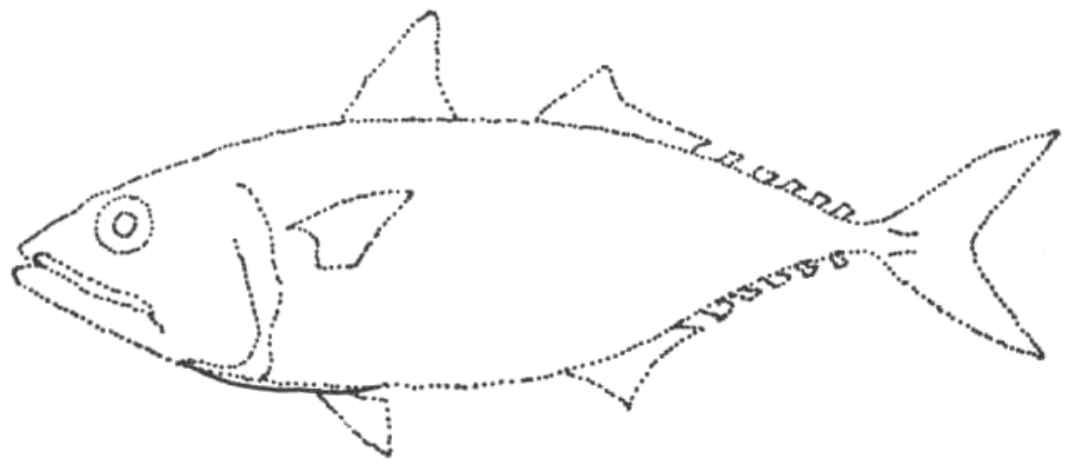

RASTRELLIGER KANAGURTA

Figure 6. Geographic Variations.

…..... from $\mathrm{Tg}$. Satai area 


\section{THE SPECIES OF RASTRELLIGER IN THE JAWA SEA}

on the lower limb in $R$. kanagurta is 2.7 and the mean is 36.6 (1.0 S.D.); in $R$. brachysoma is 2.5 and 35.8 (0.9 S.D.). Those values of the upper limb are 6.3 and 20.6 (1.3 S.D.); and 5.5 and 19.0 (1.0 S.D.) respectively. The total gill-raker counts on the first left gill-arch show overlap between species; the degree of intergradation is 19\% (Tables XXI, XXII).

Qualitative characters

Colouration. - No clear differences exist in body colouration among samples.

appearance of the cephalic lateral-line system between the two species.

Cephalic lateral-line canal. - There is an apparent difference in the

$R$. brachysoma possesses a very finely dendritic canal system whereas $R$. kanagurta has a less finely dendritic one (Fig. 7). This character is used as a key character.

Digestive tract. - The digestive tract in $R$. brachysoma is much more convoluted than that of $R$. kanagurta. This different appearance is related to the longer intestine in the first species.

The shape of the stomach differs only in the presence of a small flappy tip at the bottom of the stomach of R. kanagurta (Fig. 8).

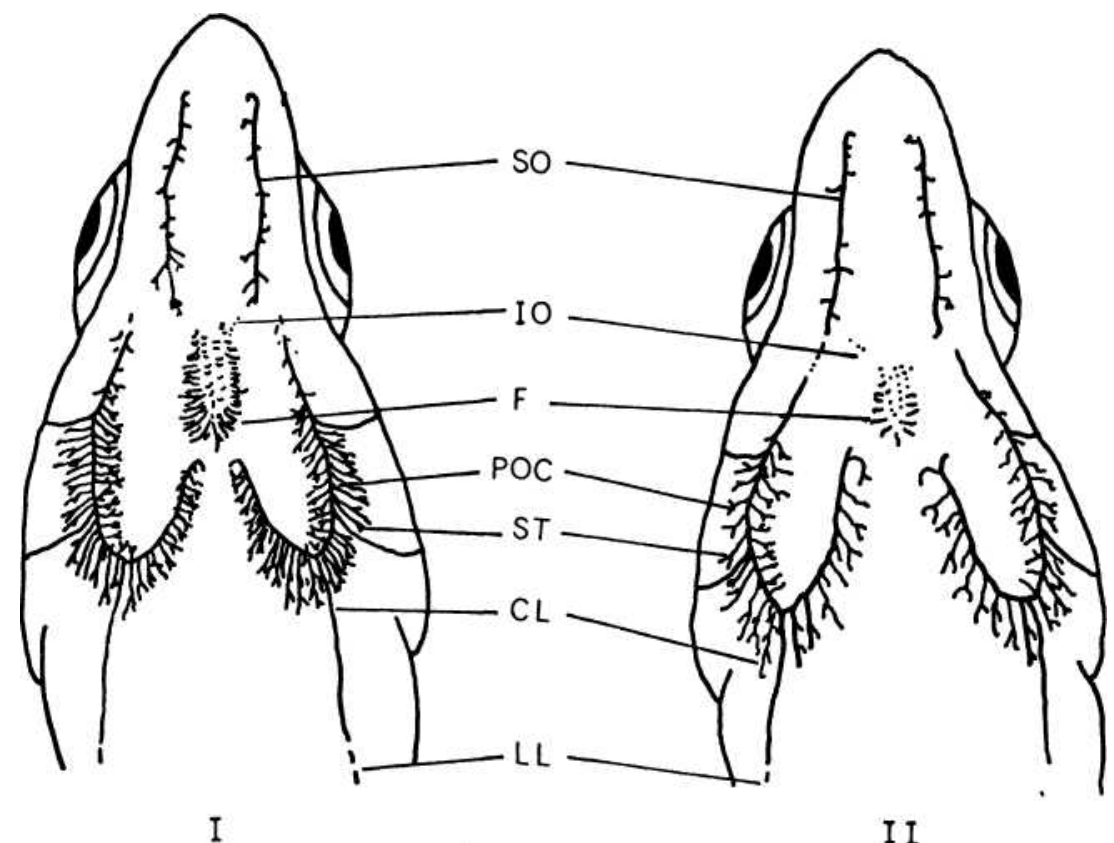

Figure 7. Cephalic lateral line system of Rastrelliger. I. R. brachysoma; II. R. kanagurta. $\mathrm{CL}=$ cephalic lateralis; $\mathrm{F}$. = frontal; $\mathbf{I O}=$ interorbital; $L L=$ linea lateralis; POC = postocular commisure; SO = supraorbital; $\mathrm{ST}=$ supratemporal. 
T. SUJASTANI
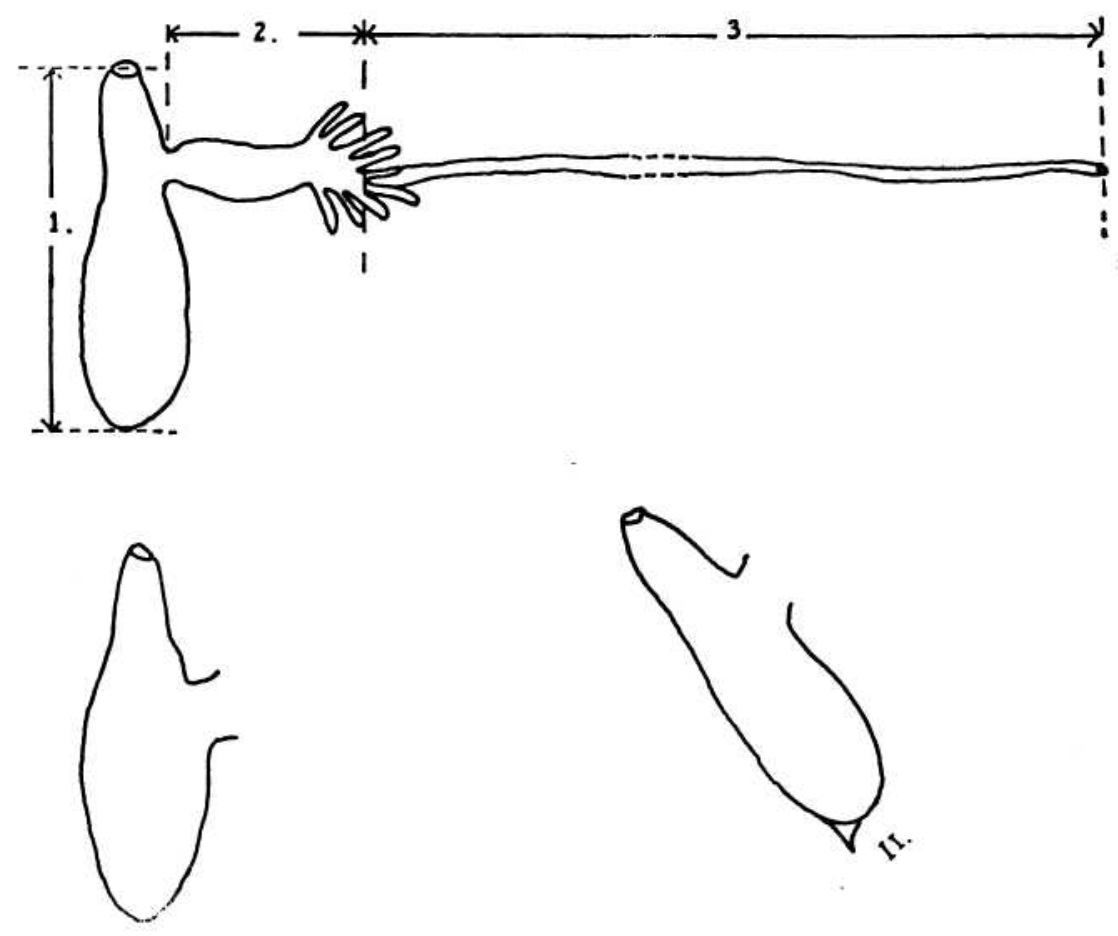

I.

Figure 8. Dimension of measurement of the digestive tract of Rastrelliger.

1. stomach; 2. pyloric; 3. intestine.

I. the stomach of $R$. brachysoma

II. the stomach of $R$. kanagurta.

\section{DISCUSSION}

The genus Rastrelliger has been accepted since the time JORDAN proposed it (JORDAN and STARKS 1908). There are two species within the genus that have caused controversy, namely Rastrelliger brachysoma BleEKER and $R$. neglectus VAN KAMPEN. Some recognize them as two valid species and others think that $R$. neglectus is a synonym of the former species. This problem probably exists because past systematic studies of marine fishes involved too few specimens and were less analytical than the systematic studies of freshwater fishes (HuBBS 1943).

The data obtained during this study suggest that in the Jawa Sea there are only two species of Rastrelliger, R. brachysoma and R. kanagurta; other species are reduced to synonyms. 


\section{THE SPECIES OF RASTRELLIGER IN THE JAWA SEA}

Rastrelliger is distributed abundantly in the Indonesian waters. This genus is caught in the Jawa Sea and contributes significantly to marine fisheries production. The problem of whether or not this Rastrelliger is composed of a number of populations has not yet been analysed. HARDENBERG'S (1938) hypothesis, based on Decapterus migration patterns, describes the Rastrelliger stocks in the area and is the only population study to have been attempted.

In order to approach the above problem and to verify the hypothesis, morphometric studies have been conducted. Four samples from two different fishing grounds were compared. The results of the comparisons of $R$. brachysoma sub-samples from Tg. Satai area suggest that longitudinal measurements and pelvic fin length are significantly different between sexes.

To avoid bias due to allometric growth, comparisons among $R$. kanagurta sub-samples from the north coast of Jawa were done by length groups. The results are that perpendicular iris, pupil diameters, pectoral fin length, and pectoral breadth are significantly different among the groups. The characters that do not exhibit either sexual dimorphism or strong allometric growth are compared among samples and the results are shown in Table XX. The results or the data suggest that $R$. brachysoma exhibits geographic variation in the dorsoventral depth, greatest body depth, and interorbital distance; $R$. kanagurta, in the head length and the dorsoventral depth. Therefore, from the standpoint of morphometry there are two different populations of Rastrelliger spp. in the Jawa Sea area which supports the HARDENBERG's hypothesis for $R$. kanagurta stocks.

The meristic characters examined do not exhibit inter or intraspecific differences. The qualitative character in distinguishing species is the appearance of the cephalic lateral-line canal system.

\section{CONCLUSION}

Analyses of morphometric data suggest that there are two species in the genus Rastrelliger, $R$. brachysoma and $R$. kanagurta. $R$. neglectus is considered to be a synonym of $R$. brachysoma. Both species exhibit intraspecific geographical variations in the dorsoventral depth, the greatest body depth, and the interorbital distance in the former species; and in the dorsoventral depth and the head depth in the latter ones.

From the stand point of morphometry there are two $R$. kanagurta populations in the Jawa Sea; this supports HARDENBERG'S hypothesis. 


\section{T. SUJASTANI}

\section{ACKNOWLEDGEMENTS}

I wish to express my appreciation and thanks to Mr. MOH. UNAR, the Director of the Marine Fisheries Research Institute.

My thanks also go to my colleagues in the above office, in the Regional Fisheries Service, and in the National Institute of Oceanology in Jakarta.

\section{REFERENCES}

AgAssiZ, J. L. R. 1874. Pisces Celebes. Icones Piscium London, U. K.

BARnARD, K. H. 1927. Monograph of the marine fishes of South Africa. Ann. S. African Mus. 21(2): 796.

BLEEKER, P. 1851. Over eenige nieuwe geslactiten en soorten van Makreelachtige visschen van den Indischen Archipel. Nat. Tijds. Ned. Ind. 1: 341 - 372. 1852. Bijdrage tot de kennis der Makreelachtige visschen van den SoendaMolukschen Archipel. Verh. Batav. Genootsch. 24:1-93. 1856. Beschrijvingen van nieuwe of weinig bekende vischsoorten van Menado en Makassar grooten deels verzameld op eene reis naar den Molukschen Archipel in het gevolg van den Gouverneur-General Duymaer van Twist. Act. Soc. Sci. Indo-Neerl. 1: 1-80.

Collette, B. B. and R. H. GiBBs 1963. Preliminary field guide to the mackerel and tuna-like fishes of the Indian-Ocean (Scombridae). U.S. Nat. Mus. Washington: 1-48.

CUVIER, G. L. C. F. D. 1817. Le regne animal distribue d'apres son organisation, pour servir de base a rhistoire naturelle des animaux et d'introduction a Panatomie comparee. Paris, 4 vols. Poissons, II: 1 - 532.

Cuvier, B. G. and A. VAlenCiEnNes 1831. Histoire naturelle des poissons. Paris VIII: 49.

DAY, F. 1870. On the Fishes of the Andaman Islands. Proc. Zool. Soc. London: $677-705$.

De Beaufort, L. F. and W. M. Chapman 1951. The Fishes of Indo-Australian Archipelago. IX. Percomorphi. E. J. Brill, Leiden: xi + 484, 89 figs.

Druzhinin, A. D. 1968 . Indian mackerel, Rastrelliger spp. in Burma waters. Proc. Indo-Pacific Fish. Conn. 13(11): 59-81.

Fowler, H. W. 1928. The fishes of Oceania. Mem. Bernice P. Bishop Mus. 10: 132,

Fraser-Brunner, A. 1950. The fishes of the family Scombridae. Ann. Mag. Nat. Hist. ser. 12,3: 131-163.

HardenberG, J. D. F. 1938. Marine biological fishery problems in the tropics. Arch. NeerlandaisesZool.3,Suppl.:65-73.

---------- 1955. A review of current knowledge of Rastrelliger. Proc. IndoPadf.Fish. Coun., Tokyo, 6th. Sess., IPFC/C55, Agenda Item 14, 25: 1-10.

HuBBS, C. L. 1943. Criteria for subspecies, species and genera, as determined by researches on fishes. Ann. N.Y. Acad. Sci. 44: $109-121$.

HubBs, C. L. and K. L. Lagler 1964. Fishes of the Great Lakes Region. Ann. Arbor. Univ. of Michigan Press (58). 
The Species Of Rastrelliger In The Jawa Sea .... (Sujastani, T)

\section{THE SPECIES OF RASTRELLIGER IN THE JAWA SEA}

JoneS, S. and E. G. SiLAS 1962. Mackerel from Andaman Sea. Symposium on Scombroid Fishes. Marine Biol. Assoc. India 1: 255 - 82.

JoRDAN, D. S. and M. C. DiCKERSON 1908. On a collection of fishes from Fiji with notes on certain Hawaiian fishes. Proc. U.S. Nat. Mus. 34: 603-617.

JORDAN, D. S. and F. S. STARKS 1908. On Rastrelliger in: On a collection of fishes from Fiji with notes on certain Hawaiian fishes by D. S. Jordan and M. C. Dickerson. Ibid.

JORDAN, D. S. and E. C. STARKS 1917. Note on a collection of fishes from Ceylon, with descriptions of new species. Pittsburg, Ann. Carnegie Mus. 11: 430 - 60.

KishinOUYE, L. 1923. Contributions to the comparative study of the so-called Scombroid fishes. Tokyo Coll. Agric. 3. 8: 406.

LESSON, R. P. 1829. Dictionaire classique d'histoire naturelle 15: 277.

MANACOP, P. R. 1956. A preliminary systematic study of the Philippine chub mackerels, family Scombridae, genera Pneumatophorus and Rastrelliger. Philippine J. Fish. 4(2): 79-101.

MATSUI, T. 1967. Review of the mackerel genera Scomber and Rastrelliger with description of a new species of Rastrelliger. Copeia 1: 71 - 83.

Roedel, P. M. 1952. A racial study of the Pacific Mackerel, Pneumatophorus diego. Fish. Bull, Sacramento 84: 53 p.

ROYCE, W. F. 1957. Statistical comparison of morphological data in: John Marr's Contribution to the study of subpopulations of fishes. U.S. Dept. Int., Fish and wildl. Ser., Special Sci. Repp. Fish. 208: 7-28.

Ruppell, W. P. E. S. 1835 . Neue Wirbelthiere. Fische des Rothen Meeres 10-38.

STARKS, E. C. 1921. A key to the families of marine fishes of the West Coast. Calif. State Fish and Games, Comm. Fish. Bull. 5: 16 p.

VAn Kampen, P. N. 1907. Uber zwei Scomber - Arten des indischen Archipels. Bull. Dept. Agric. Indes. Neerl. 8 (Zool. 2) 1-8.

Whitley, G. P. 1944. New sharks and fishes from Western Australia. Aust. Zool. 10: 252-273. 


\section{T. SUjastani}

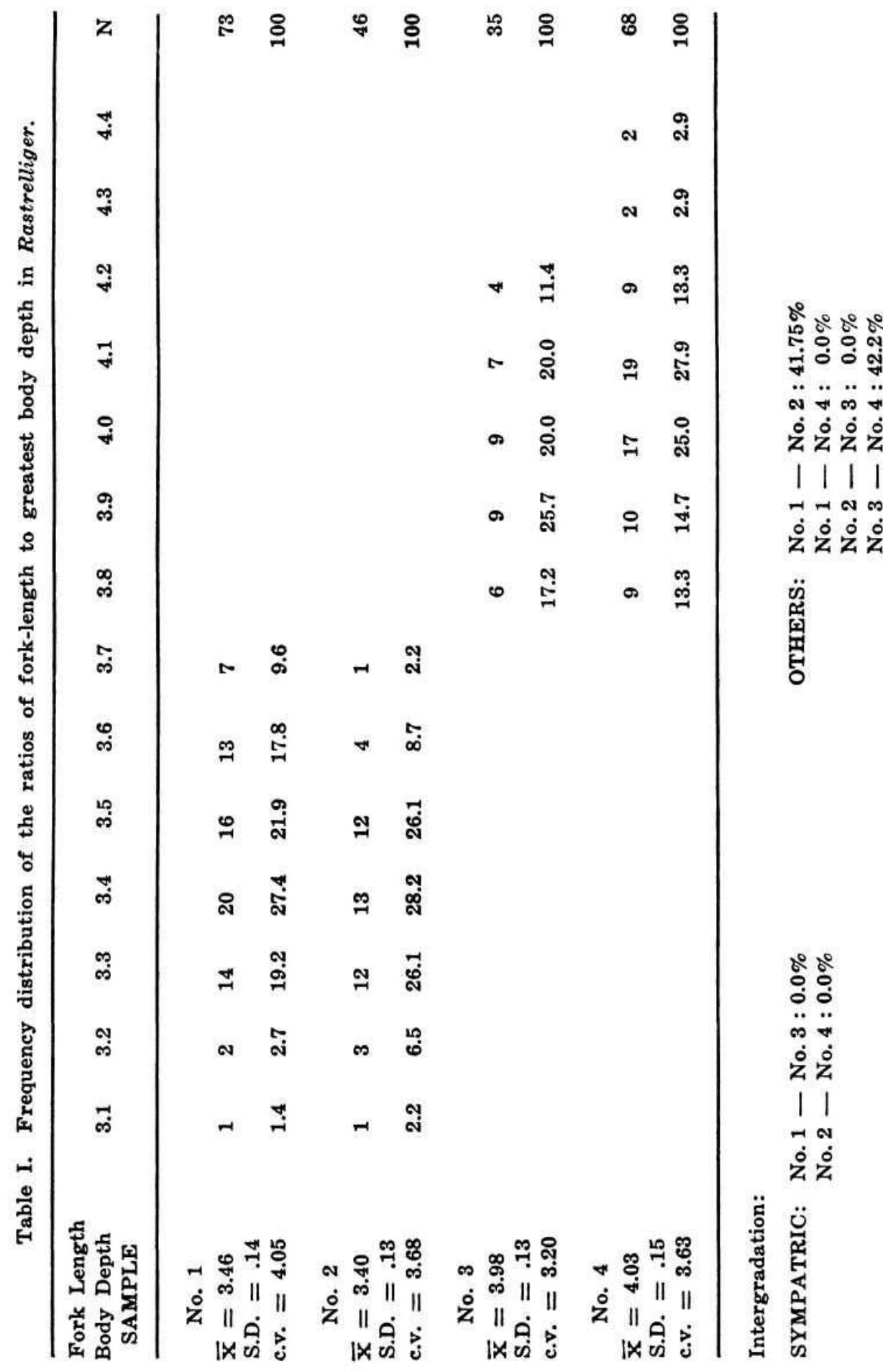


THE SPECIES OF RASTRELLIGER IN THE JAWA SEA

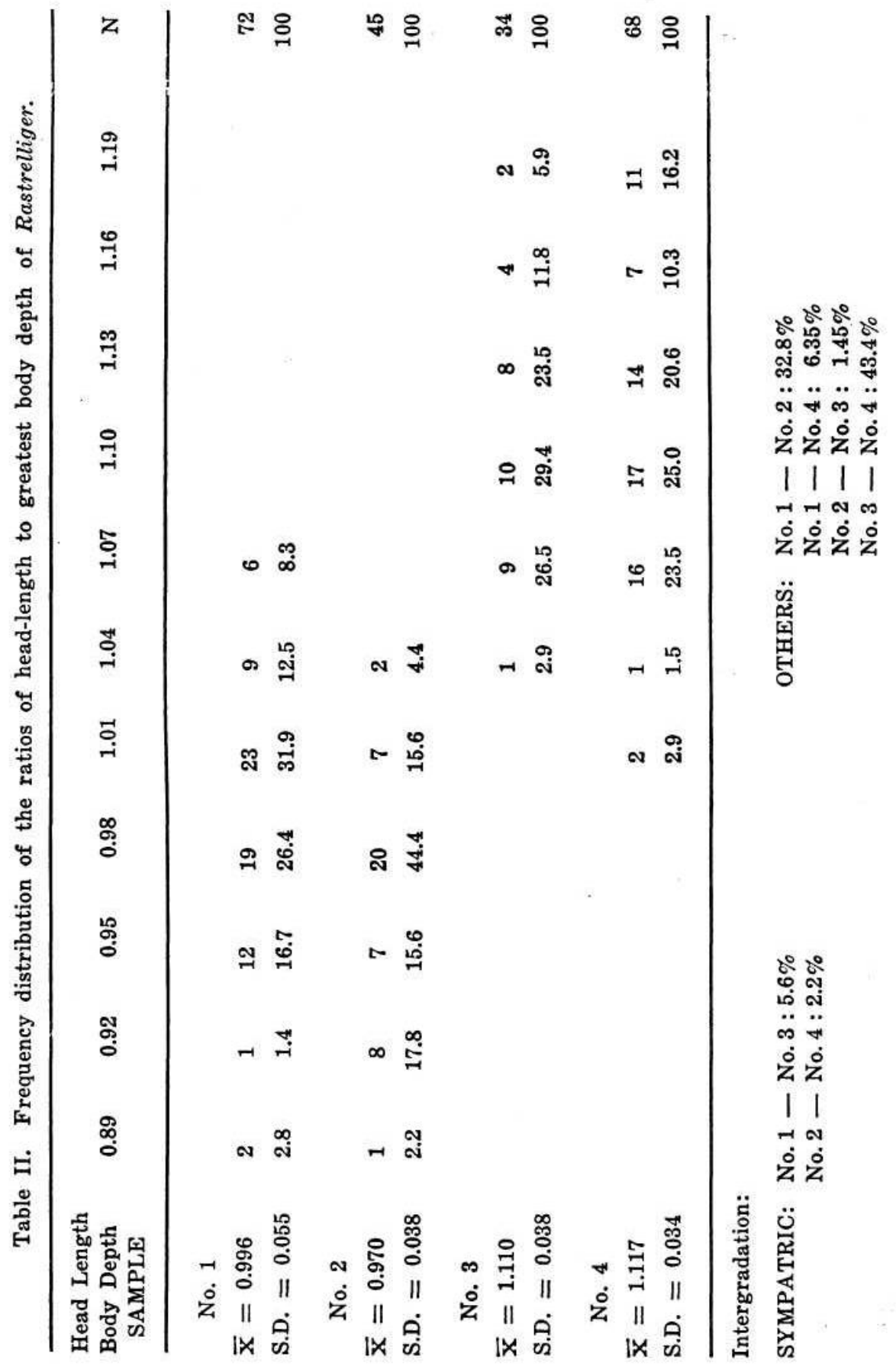




\section{T. SUJASTANI}

Table III. Ratios of the length of intestine to fork-length of Rastrelliger.

\begin{tabular}{cccccc}
\hline SAMPLE & Fork-Length & $\begin{array}{c}\text { Intestine } \\
\text { Fork Length }\end{array}$ & SAMPLE & Fork-Length & $\begin{array}{c}\text { Intestine } \\
\text { Fork Length }\end{array}$ \\
\hline No. 1 & 17.671 & 2.48 & No. 3 & 20.434 & 1.38 \\
& 17.887 & 2.51 & & 18.028 & 1.35 \\
& 18.238 & 2.56 & & 19.988 & 1.37 \\
& 18.524 & 2.60 & & 19.694 & 1.35 \\
X $=$ & 18.170 & 2.55 & & 17.609 & 1.33 \\
No. 2 & 18.098 & 2.54 & & 19.151 & 1.36 \\
& 17.535 & 2.95 & No. 4 & 18.147 & 1.32 \\
& 16.351 & 2.22 & & 19.507 & 1.38 \\
& 16.207 & 2.42 & & 18.693 & 1.36 \\
& 17.479 & 2.61 & & 18.802 & 1.33 \\
& 18.747 & 2.80 & & & \\
& 15.437 & 2.31 & & 18.787 & 1.35 \\
\hline
\end{tabular}

Intergradation between sympatric groups: $\quad$ No. 1 - No. $3: 0.0 \%$.

No. 2 - No. $4: 0.0 \%$.

Table IV. Morphometric measurements of Rastrelliger brachysoma BLEEKER

$$
(\mathbf{n}=117) \text {. }
$$

\begin{tabular}{|c|c|c|c|c|}
\hline No. & Character & Mean & $\begin{array}{l}\text { Standard } \\
\text { Error }\end{array}$ & Range \\
\hline 1. & Fork Length & 15.50 & 1.39 & $12.20-18.20$ \\
\hline 2. & Total Length & 17.40 & 1.63 & $13.70-20.50$ \\
\hline 3. & Body Length & 14.09 & 1.29 & $11.10-16.50$ \\
\hline 4. & Head Length & 4.45 & 0.43 & $3.50-5.30$ \\
\hline 5. & Maxillary Length & 2.46 & 0.29 & $1.80-3.10$ \\
\hline 6. & Head Depth & 3.54 & 0.37 & $2.70-4.40$ \\
\hline 7. & Dorsoventral Depth & 4.40 & 0.48 & $3.30-5.60$ \\
\hline 8. & Dorsoanal Depth & 4.17 & 0.42 & $3.20-5.10$ \\
\hline 9. & Greatest Depth & 4.53 & 0.50 & $3.40-5.80$ \\
\hline 10. & Perp. Iris Diam. & 0.91 & 0.09 & $0.70-1.20$ \\
\hline 11. & Perp. Pupil Diam. & 0.49 & 0.05 & $0.30-0.70$ \\
\hline 12. & Pectoral Fin Length & 2.19 & 0.25 & $1.60-2.70$ \\
\hline 13. & Pelvic Fin Length & 1.90 & 0.23 & $1.40-2.90$ \\
\hline 14. & Interorbital Distance & 0.94 & 0.12 & $0.60-1.30$ \\
\hline 15. & Pectoral Breadth & 2.10 & 0.28 & $1.40-2.70$ \\
\hline
\end{tabular}


THE SPECIES OF RASTRELLIGER IN THE JAWA SEA

Table V. Morphometric measurements of Rastrelliger kanagurta CUVIER

$$
(\mathbf{n}=103) \text {. }
$$

\begin{tabular}{|c|c|c|c|c|}
\hline \multirow[b]{2}{*}{ No. } & \multirow[b]{2}{*}{ Character } & \multicolumn{3}{|c|}{ Standard } \\
\hline & & Mean & Error & Range \\
\hline 1. & Fork Length & 17.41 & 2.08 & $13.90-21.90$ \\
\hline 2. & Total Length & 19.39 & 2.35 & $15.40-24.40$ \\
\hline 3. & Body Length & 15.98 & 1.90 & $12.60-20.00$ \\
\hline 4. & Head Length & 4.84 & 0.57 & $3.90-6.20$ \\
\hline 5. & Maxillary Length & 2.48 & 0.35 & $1.80-3.30$ \\
\hline 6. & Head Depth & 3.39 & 0.43 & $2.60-4.40$ \\
\hline 7. & Dorsoventral Depth & 4.27 & 0.54 & $3.10-5.50$ \\
\hline 8. & Dorsoanal Depth & 4.06 & 0.52 & $3.10-5.20$ \\
\hline 9. & Greatest Depth & 4.35 & 0.58 & $3.30-5.60$ \\
\hline 10. & Perp. Iris Diam. & 1.03 & 0.14 & $0.80-1.50$ \\
\hline 11. & Perp. Pupil Diam. & 0.57 & 0.07 & $0.40-0.80$ \\
\hline 12. & Pectoral Fin Length & 2.29 & 0.33 & $1.70-3.10$ \\
\hline 13. & Pelvic Fin Length & 1.93 & 0.27 & $1.20-2.60$ \\
\hline 14. & Interorbital Distance & 1.02 & 0.16 & $0.70-1.40$ \\
\hline 15. & Pectoral Breadth & 2.32 & 0.38 & $1.60-3.20$ \\
\hline
\end{tabular}

Table VI. Regressions of sample No. 1 from the north coast of Jawa, $\mathbf{N}=72$.

\begin{tabular}{|c|c|c|c|c|c|c|c|}
\hline No. & $\begin{array}{l}\text { Charac- } \\
\text { ter }\end{array}$ & $\mathbf{a}$ & b & $\begin{array}{l}\text { St. Error } \\
\text { of } \mathbf{b}\end{array}$ & $\mathbf{r}$ & c.v. & $\mathbf{T}$ \\
\hline 2. & TL & -0.2360 & 1.1420 & 0.0292 & 0.9778 & 1.37 & 39.0 \\
\hline 3. & BL & 0.0292 & 0.9076 & 0.0234 & 0.9774 & 1.36 & 38.7 \\
\hline 4. & $\mathbf{L G}^{\prime}$ & 0.0187 & 0.2880 & 0.0123 & 0.9416 & 2.25 & 23.4 \\
\hline 5. & UJ & -0.5541 & 0.1959 & 0.0099 & 0.9203 & 3.27 & 19.6 \\
\hline 6. & YJ' & -0.2071 & 0.2427 & 0.0121 & 0.9225 & 2.79 & 19.9 \\
\hline 7. & D1V & -1.0954 & 0.3531 & 0.0188 & 0.9132 & 3.51 & 18.7 \\
\hline 8. & D2A & -0.7110 & 0.3138 & 0.0185 & 0.8960 & 3.65 & 16.8 \\
\hline 9. & $\mathbf{h}$ & -1.0948 & 0.3606 & 0.0207 & 0.9008 & 3.77 & 17.3 \\
\hline 10. & Ih & 0.0716 & 0.0550 & 0.0065 & 0.7078 & 5.82 & 8.3 \\
\hline 11. & Eh & 0.0766 & 0.0270 & 0.0032 & 0.7105 & 5.30 & 8.4 \\
\hline 12. & $\mathbf{P h}$ & -0.3756 & 0.1676 & 0.0092 & 0.9078 & 3.40 & 18.1 \\
\hline 13. & Vh & -0.3765 & 0.1483 & 0.0165 & 0.7303 & 7.04 & 8.9 \\
\hline 14. & OO & -0.3006 & 0.0805 & 0.0053 & 0.8742 & 4.59 & 15.0 \\
\hline 15. & $\mathbf{P P}$ & -1.0682 & 0.2019 & 0.0152 & 0.8452 & 6.00 & 13.2 \\
\hline
\end{tabular}


T. SUJASTANI

Table VII. Regressions of sample No. 2 from Tg. Satai area, N $=45$.

\begin{tabular}{rcccccrr}
\hline No. & $\begin{array}{c}\text { Charac- } \\
\text { ter }\end{array}$ & a & b & $\begin{array}{c}\text { St. Error } \\
\text { of b }\end{array}$ & r & c.v. & T \\
\hline 2. & TL & -0.3889 & 1.1413 & 0.0131 & 0.9972 & 0.93 & 86.8 \\
& & & & & & & \\
3. & BL & -0.1711 & 0.9199 & 0.0060 & 0.9991 & 0.52 & 151.2 \\
4. & LG' & -0.1638 & 0.2854 & 0.0071 & 0.9875 & 1.99 & 41.0 \\
5. & UJ & -0.6566 & 0.1996 & 0.0067 & 0.9766 & 3.39 & 29.7 \\
6. & YJ' & -0.5317 & 0.2621 & 0.0079 & 0.9807 & .2 .78 & 32.8 \\
7. & D1V & -0.6542 & 0.3283 & 0.0102 & 0.9797 & 2.84 & 32.0 \\
8. & D2A & -0.1514 & 0.2807 & 0.0106 & 0.9704 & 3.11 & 26.3 \\
9. & h & -0.7970 & 0.3476 & 0.0105 & 0.9810 & 2.81 & 33.1 \\
10. & Ih & -0.0264 & 0.0595 & 0.0029 & 0.9517 & 4.00 & 20.3 \\
11. & Eh & -0.1340 & 0.0413 & 0.0025 & 0.9266 & 6.23 & 16.1 \\
12. & Ph & -0.3636 & 0.1626 & 0.0053 & 0.9777 & 3.04 & 30.5 \\
13. & Vh & -0.2306 & 0.1350 & 0.0074 & 0.9409 & 4.89 & 18.2 \\
14. & OO & -0.2462 & 0.0763 & 0.0050 & 0.9163 & 6.70 & 15.0 \\
15. & PP & -0.7629 & 0.1881 & 0.0081 & 0.9619 & 4.68 & 23.0 \\
& & & & & & & \\
\hline
\end{tabular}

Table VIII. Regressions of sample No. 3 from the north coast of Jawa, $\mathbf{N}=35$.

\begin{tabular}{|c|c|c|c|c|c|c|c|}
\hline No. & $\begin{array}{c}\text { Charac- } \\
\text { ter }\end{array}$ & $\mathbf{a}$ & b & $\begin{array}{l}\text { St. Error } \\
\text { of } b\end{array}$ & $\mathbf{r}$ & c.v. & $\mathbf{T}$ \\
\hline 2. & TL & -0.3424 & 1.1353 & 0.0302 & 0.9885 & 1.23 & 37.5 \\
\hline 3. & BL & -0.2741 & 0.9318 & 0.0153 & 0.9955 & 0.76 & 60.5 \\
\hline 4. & LG' & -0.0060 & 0.2800 & 0.0090 & 0.9831 & 1.47 & 30.8 \\
\hline 5. & $\mathbf{U J}$ & -0.4448 & 0.1700 & 0.0085 & 0.9610 & 2.65 & 19.9 \\
\hline 6. & $\mathbf{Y J}$ & 0.0842 & 0.1920 & 0.0101 & 0.9567 & 2.35 & 18.8 \\
\hline 7. & D1V & 0.3913 & 0.2229 & 0.0126 & 0.9507 & 2.35 & 17.6 \\
\hline 8. & D2A & 0.2400 & 0.2219 & 0.0122 & 0.9533 & 2.36 & 18.1 \\
\hline 9. & $\mathbf{h}$ & 0.1010 & 0.2460 & 0.0163 & 0.9344 & 2.94 & 15.0 \\
\hline 10. & Ih & -0.1854 & 0.0709 & 0.0069 & 0.8713 & 5.19 & 10.2 \\
\hline 11. & Eh & $-0.1-16$ & 0.0386 & 0.0035 & 0.8832 , & 4.90 & 10.8 \\
\hline 12. & $\mathbf{P h}$ & -0.3866 & 0.1555 & 0.0100 & 0.9374 & 3.39 & 15.4 \\
\hline 13. & Vh & -0.2247 & 0.1250 & 0.0080 & 0.9382 & 3.23 & 15.5 \\
\hline 14. & OO & -0.0523 & 0.0616 & 0.0066 & 0.8485 & 5.16 & 9.2 \\
\hline 15. & PP & -0.9698 & 0.1916 & 0.0093 & 0.9631 & 3.05 & 20.5 \\
\hline
\end{tabular}


THE SPECIES OF RASTRELLIGER IN THE JAWA SEA

Table IX. Regressions of sample No. 4 from Tg. Satai area, $N=68$.

\begin{tabular}{|c|c|c|c|c|c|c|c|}
\hline No. & $\begin{array}{c}\text { Charac- } \\
\text { ter }\end{array}$ & $\mathbf{a}$ & b & $\begin{array}{l}\text { St. Error } \\
\text { of } \mathbf{b}\end{array}$ & $\mathbf{r}$ & c.v. & $\mathbf{T}$ \\
\hline 2. & TL & -0.0062 & 1.1119 & 0.0124 & 0.9959 & 1.21 & 89.3 \\
\hline 3. & BL & 0.1484 & 0.9090 & 0.0068 & 0.9981 & 0.80 & 133.0 \\
\hline 4. & LG' & 0.1895 & 0.2660 & 0.0051 & 0.9881 & 1.99 & 52.0 \\
\hline 5. & UJ & -0.2823 & 0.1578 & 0.0041 & 0.9778 & 3.19 & 37.8 \\
\hline 6. & YJ' & -0.1815 & 0.2041 & 0.0044 & 0.9845 & 2.50 & 45.6 \\
\hline 7. & D1V & -0.3092 & 0.2599 & 0.0065 & 0.9798 & 2.92 & 39.7 \\
\hline 8. & D2A & -0.2785 & 0.2487 & 0.0057 & 0.9831 & 2.65 & 43.5 \\
\hline 9. & h & -0.4484 & 0.2754 & 0.0071 & 0.9786 & 3.09 & 38.6 \\
\hline 10. & Ih & -0.0524 & 0.0620 & 0.0030 & 0.9302 & 5.52 & 20.5 \\
\hline 11. & Eh & 0.0695 & 0.0285 & 0.0018 & 0.8801 & 6.27 & 15.0 \\
\hline 12. & Ph & -0.3793 & 0.1526 & 0.0044 & 0.9728 & 3.71 & 34.1 \\
\hline 13. & Vh & -0.2536 & 0.1253 & 0.0039 & 0.9691 & 3.84 & 31.9 \\
\hline 14. & 00 & -0.2862 & 0.0752 & 0.0033 & 0.9417 & 6.12 & 22.7 \\
\hline 15. & pp & -0.5646 & 0.1642 & 0.0063 & 0.9438 & 5.25 & 25.7 \\
\hline
\end{tabular}

Note: $y=a+b x$; Where: $x$ is fork length,

$\mathrm{y}$ is measurement of any body part,

$r$ is correlation coefficient,

c.v. is coefficient of variation (\%),

$\mathrm{T}$ is the Student's t-value.

Table X. Comparison of body proportions of Rastrelliger spp. by covariance analysis for the males and females taken from Tg. Satai.

Data show Variance Ratio and its significance.

\begin{tabular}{llll}
\hline \multicolumn{1}{c}{ Character } & Fr & Fb & Fa \\
\hline Total length & $3.91^{* *}$ & 0.14 & $5.58^{*}$ \\
Body length & $6.46^{* * *}$ & 0.07 & 1.97 \\
Head length & 1.35 & $7.38^{* *}$ & $(0.05)$ \\
Maxillary length & 1.36 & $5.32^{*}$ & 0.51 \\
Head depth & 2.11 & 1.89 & 0.49 \\
Dorsoventral depth & 1.03 & 0.89 & 0.36 \\
Dorsoanal depth & 1.94 & 1.52 & 0.00007 \\
Greatest body depth & 1.00 & 1.90 & 0.33 \\
Per p. iris diameter & 1.16 & 2.62 & 0.02 \\
Perp. pupil diameter & 1.80 & 0.87 & 2.59 \\
Pectoral fin length & 2.02 & 0.17 & 2.18 \\
Pelvic fin length & $14.88^{* * *}$ & 0.001 & 1.63 \\
Interorbital distance & 1.24 & 1.10 & 0.91 \\
Pectoral breadth & 1.05 & 1.04 & 0.000003 \\
\hline
\end{tabular}

Note: The above species was named Rastrelliger brachysoma. 


\section{T. SUJASTANI}

Table XI. Comparison of body proportions of Rastrelliger spp. by covariance analysis between classmodes of $20.0 \mathrm{~cm}$ fork-length $(17.5-22.4 \mathrm{~cm})$ and of $16.0 \mathrm{~cm}$ fork length $(14.5-17.4 \mathrm{~cm})$ taken from Tg. Satai area.

\begin{tabular}{llcc}
\hline \multicolumn{1}{c}{ Character } & Fr & Fb & Fa \\
\hline Maxillary length & 1.40 & $6.12^{*}$ & 0.95 \\
Head depth & 1.67 & 1.51 & 1.25 \\
Dorsoventral depth & 1.15 & 0.09 & 2.14 \\
Dorsoanal depth & 1.35 & 0.81 & 1.05 \\
Greatest body depth & 1.18 & 1.54 & 0.65 \\
Perp. iris diameter & $2.32^{*}$ & $13.97^{* * *}$ & $(2.54)$ \\
Perp. pupil diameter & 1.29 & $14.34^{* * *}$ & $(2.84)$ \\
Pectoral fin length & 1.58 & $4.03^{*}$ & 0.68 \\
Interorbital distance & 1.12 & 1.91 & 0.53 \\
Pectoral breadth & $3.27^{* *}$ & 0.81 & 0.07 \\
\hline
\end{tabular}

Note: The above species was named Rastrelliger kanagurta,

* $\quad$ Significant at 5\% level.

** Significant at $1 \%$ level.

*** Significant at $0.1 \%$ level.

Table XII. Comparison of body proportions of Rastrelliger spp. by covariance analysis between classmodes of $20.0 \mathrm{~cm}$ fork-length $(17.5-22.4 \mathrm{~cm})$ and of $14.0 \mathrm{~cm}$ fork-length $(13.5-14.4 \mathrm{~cm})$ taken from Tg. Satai.

\begin{tabular}{llcc}
\hline \multicolumn{1}{c}{ Character } & Fr & Fb & Fa \\
\hline Maxillary length & 1.56 & 0.67 & $12.20^{* *}$ \\
Head depth & 1.40 & 0.91 & $4.86^{*}$ \\
Dorsoventral depth & 1.04 & 0.52 & 0.58 \\
Dorsoanal depth & 2.03 & 0.06 & 0.17 \\
Greatest body depth & 2.88 & 0.01 & 0.12 \\
Perp. iris diameter & 2.62 & 2.27 & $13.87^{* * *}$ \\
Perp. Pupil diameter & 1.07 & 0.001 & $21.83^{* * *}$ \\
Pectoral fin length & 1.19 & 1.49 & $8.17^{* *}$ \\
Interorbital distance & 1.37 & 1.55 & 3.06 \\
Pectoral breadth & 2.29 & 0.10 & 0.67 \\
\hline
\end{tabular}




\section{THE SPECIES OF RASTRELLIGER IN THE JAWA SEA}

Table XIII. Comparison of body proportions of Rastrelliger spp. by covariance analysis between classmodes of $16.00 \mathrm{~cm}$ fork-length $(14.5-17.4 \mathrm{~cm})$ and of 14.00 $\mathrm{cm}$ fork-length $(13.5-14.4 \mathrm{~cm})$ taken from Tg. Satai.

\begin{tabular}{lcll}
\hline \multicolumn{1}{c}{ Character } & Fr & Fb & Fa \\
\hline Maxillary length & 0.10 & 0.11 & 2.32 \\
Head depth & 1.18 & 2.08 & 1.04 \\
Dorsoventral depth & 1.10 & 0.09 & 0.11 \\
Dorsoanal depth & 1.49 & 0.003 & 0.04 \\
Greatest body depth & 2.42 & 0.02 & 0.30 \\
Perp. iris diameter & 1.12 & 1.07 & 0.39 \\
Perp. pupil diameter & 1.20 & 0.65 & 0.45 \\
Pectoral fin length & 1.32 & 0.89 & 2.56 \\
Interorbital distance & 1.22 & 2.61 & 0.003 \\
Pectoral breadth & 1.12 & 0.05 & 0.01 \\
\end{tabular}

Note: The above species was named Rastrelliger kanagurta.

Fr is the variance ratio and its significance of the regression difference. $\mathrm{Fb}$ to test the regression coefficient difference.

Fa to test the adjusted mean difference.

In the case where the regression coefficient difference is significant, the test of the adjusted mean becomes inappropriate.

Table XIV. Comparison of body proportions of Rastrelliger spp. by covariance analysis between sample No. 1 and sample No. 2 from Jakarta and Tg. Satai respectively.

\begin{tabular}{lcll}
\hline \multicolumn{1}{c}{ Character } & Fr & Fb & Fa \\
\hline Head depth & 1.15 & 1.81 & 1.26 \\
Dorsoventral depth & $1.65^{*}$ & 1.37 & 3.90 \\
Dorsoanal depth & 1.49 & 2.42 & 2.36 \\
Greatest body depth & $1.92^{*}$ & 0.31 & $9.90^{* *}$ \\
Interorbital distance & $1.82^{*}$ & 0.31 & 1.15 \\
\hline
\end{tabular}

Table XV. Comparison of body proportions of Rastrelliger spp. by covariance analysis between samples No. 3 (Jakarta) and No. 4 (Tg. Satai).

\begin{tabular}{llll}
\hline \multicolumn{1}{c}{ Character } & Fr & Fb & Fa \\
\hline Head depth & 1.05 & 1.20 & $6.51^{*}$ \\
Dorsoventral depth & 1.28 & $5.89^{*}$ & 1.54 \\
Dorsoanal depth & 1.05 & 3.80 & 2.23 \\
Greatest body depth & 1.07 & 2.80 & 0.39 \\
Interorbital distance & 1.19 & 3.03 & 0.84 \\
\hline
\end{tabular}




\section{T. SUJASTANI}

Table XVI. Comparison of body proportions of Rastrelliger spp. by covariance analysis between samples No. 1 (Jakarta) and No. 3 (Jakarta).

\begin{tabular}{llcl}
\hline \multicolumn{1}{c}{ Character } & Fr & Fb & Fa \\
\hline Head depth & 1.44 & $9.41^{* *}$ & $(>1)$ \\
Dorsoventral depth & $2.21^{*}$ & $28.92^{* * *}$ & $(>1)$ \\
Dorsoanal depth & $2.31^{* *}$ & $14.83^{* * *}$ & $(>1)$ \\
Greatest body depth & 1.62 & $17.26^{* * *}$ & $(>1)$ \\
Interorbital distance & 1.54 & $5.26^{*}$ & $25.41^{* * *}$ \\
\hline
\end{tabular}

* Significant at $5 \%$ level.

$* *$ Significant at $1 \%$ level.

*** Significant at $0.1 \%$ level.

Table XVII. Comparison of body proportions of Rastrelliger spp. by covariance analysis between samples No. 2 (Tg. Satai) and No. 4 (Tg. Satai).

\begin{tabular}{lccc}
\hline \multicolumn{1}{c}{ Character } & Fr & Fb & Fa \\
\hline Head depth & 1.31 & $43.43^{* * *}$ & $(>1)$ \\
Dorsoventral depth & 1.04 & $31.96^{* * *}$ & $(>1)$ \\
Dorsoanal depth & 1.46 & $7.80^{* *}$ & $(>1)$ \\
Greatest body depth & 1.09 & $31.39^{* * *}$ & $(>1)$ \\
Interorbital distance & 1.009 & 0.03 & $19.82^{* * *}$ \\
\hline
\end{tabular}

Table XVIII. Comparison of body proportions of Rastrelliger spp. by covariance analysis between samples No. 2 (Tg. Satai) and No. 3 (Jakarta).

\begin{tabular}{lccc}
\hline \multicolumn{1}{c}{ Character } & Fr & Fb & Fa \\
\hline Head depth & 1.25 & $27.65^{* * *}$ & $(>1)$ \\
Dorsoventral depth & 1.34 & $38.75^{* * *}$ & $(>1)$ \\
Dorsoanal depth & 1.54 & $11.73^{* * *}$ & $(>1)$ \\
Greatest body depth & 1.18 & $28.36^{* * *}$ & $(>1)$ \\
Interorbital distance & 1.18 & 2.93 & $9.87^{* *}$ \\
\hline
\end{tabular}


THE SPECIES OF RASTRELLIGER IN THE JAWA

Table XIX. Comparison of body proportions of Rastrelliger spp. by covariance analysis between samples No. 1 (Jakarta) and No. 4 (Tg. Satai).

\begin{tabular}{llcc}
\hline \multicolumn{1}{c}{ Character } & Fr & Fb & Fa \\
\hline Head depth & 1.52 & $9.84^{* *}$ & $(>1)$ \\
Dorsoventral depth & $1.72^{*}$ & $25.61^{* * *}$ & $(>1)$ \\
Dorsoanal depth & $2.18^{* *}$ & $13.79^{* * *}$ & $(>1)$ \\
Greatest body depth & $1.75^{*}$ & $17.65^{* * *}$ & $(>1)$ \\
Interorbital distance & $1.84^{*}$ & 0.56 & $54.49^{* * *}$ \\
\hline
\end{tabular}

* Significant at $5 \%$ level.

** Significant at $1 \%$ level.

*** Significant at $0.1 \%$ level.

Table XX. Covariance analyses for pairs of Rastrelliger. $\mathrm{Fr}, \mathrm{Fb}$ and $\mathrm{Fa}$ are the variance ratios used to test the significance of difference in regression line, regression coefficient, and adjusted mean respectively.

\begin{tabular}{|c|c|c|c|c|c|c|c|c|c|c|}
\hline $\begin{array}{l}\text { Sample } \\
\text { Number }\end{array}$ & $\begin{array}{l}\text { Morphometric } \\
\text { Character }\end{array}$ & & No. 1 & & & & & & & \\
\hline \multirow[b]{2}{*}{ No. 2} & $\begin{array}{l}\text { Head depth } \\
\text { Dorsoventral depth }\end{array}$ & $*$ & & & & & & & & \\
\hline & $\begin{array}{l}\text { Dorsoanal depth } \\
\text { Greatest body depth } \\
\text { Interorbital distance } \\
\text { Head depth } \\
\text { Dorsoventral depth }\end{array}$ & $\begin{array}{l}* \\
* \\
*\end{array}$ & $\begin{array}{l}* * \\
* * *\end{array}$ & $* *$ & & $\begin{array}{l}\text { No. } 2 \\
* * * * \\
* * *\end{array}$ & & & & \\
\hline No. 3 & $\begin{array}{l}\text { Dorsoanal depth } \\
\text { Greatest body depth } \\
\text { Interorbital distance } \\
\text { Head depth } \\
\text { Dorsoventral depth }\end{array}$ & $* *$ & $\begin{array}{l}* * * * \\
* * * * \\
* \\
* *\end{array}$ & $* * *$ & & $\begin{array}{l}* * * * \\
* * * \\
* * * \\
* * *\end{array}$ & $* *$ & & $\begin{array}{l}\text { No. } 3 \\
*\end{array}$ & * \\
\hline \multirow[t]{2}{*}{ No. 4} & $\begin{array}{l}\text { Dorsoanal depth } \\
\text { Greatest body depth } \\
\text { Interorbital distance }\end{array}$ & $\begin{array}{l}* * \\
* \\
*\end{array}$ & $\begin{array}{l}* * * \\
* * *\end{array}$ & $* * *$ & & $\begin{array}{l}* * * \\
* * *\end{array}$ & *** & & & \\
\hline & & Fr & $\mathrm{Fb}$ & $\mathrm{Fa}$ & Fr & $\mathrm{Fb}$ & $\mathrm{Fa}$ & Fr & $\mathrm{Fb}$ & $\mathrm{Fa}$ \\
\hline
\end{tabular}

* Significant at $5 \%$ level.

** Significant at $1 \%$ level.

*** Significant at $0.1 \%$ level.

\section{SEA}




\section{T. SUJASTANI}

Table XXI. Gill-raker counts of Rastrelliger.

\begin{tabular}{lccccc}
\hline \multirow{2}{*}{ Species Name } & Part of Gill & & \multicolumn{3}{c}{ Coefficient of } \\
& Arch & Mean & S.D. & Variations & N \\
\hline R. brachysoma & Uppre & 19.0 & 1.0 & 5.47 & 14 \\
& Lower & 35.8 & 0.9 & 2.46 & 25 \\
& Total & 55.0 & 1.0 & 1.82 & 15 \\
R. kanagurta & Upper & 20.6 & 1.3 & 6.27 & 28 \\
& Lower & 36.6 & 1.0 & 2.73 & 30 \\
& Total & 57.2 & 1.9 & 3.27 & 28 \\
& & & & & \\
\hline
\end{tabular}

Table XXII. The degree of intergradation of the total gill raker counts of the first left gill-arch of Rastrelliger.

\begin{tabular}{lcrrrrrr}
\hline $\begin{array}{l}\text { Gill Raker } \\
\text { Count in \% } \\
\text { Species }\end{array}$ & 54 & 55 & 56 & 57 & 58 & 59 & $\mathrm{n}$ \\
\hline $\boldsymbol{R}$. brachysoma & 40 & 26.7 & 26.7 & & - & - & 100 \\
R. kanagurta & 14.3 & 7.1 & 10.7 & 21.4 & 25.0 & 21.4 & 99.9 \\
\hline
\end{tabular}

Intergradation $=19 \%$. 